\title{
Application of Bloomian and Marzanoian Higher Order Thinking Skills in the Physics Learning Assessment: an Inevitability
}

\author{
Edi Istiyono, Wipsar Sunu Brams Dwandaru, Intan Megawati, Ermansah \\ Physics Education Study Program, Graduate School \\ Yogyakarta State University \\ Yogyakarta, Indonesia \\ edi_istiyono@uny.ac.id
}

\begin{abstract}
Assessment in learning is perceived to be effective when it can measure the abilitis of students. Assessment in the $21^{\text {st }}$ century emphasizes more on the realm of high-level abilitis. The objectives of this study were i) comparing Bloomian and Marizanoian higher order thinking skills (HOTS) in terms of construction and characteristics, and also ii) knowing the feasibility of applying the aforementioned two types of HOTS upon physics learning assessment. The Bloomian and Marzanoian HOTS instruments were developed by modifying the Wilson and Oriondo-Antonio models. The development models uutilized were 1) design test, 2) trial test, and 3) assembling test. The respondents for the trial were 737 public senior high school students in Yogyakarta Special Region. The results showed that 1) Bloomian HOTS consisting of 3 aspects, 8 sub-aspects, and 62 items with the most difficult aspect was create, while Marzanoian HOTS consisting of 5 aspects, 13 sub-aspects, and 63 items with the most difficult aspect was knowledge utilization. All items with subject material of Hooke's law, static fluids, temperature and heat, and optical devices were valid and fit with PCM, and also reliable; and 2) Bloomian and Marzanoian HOTS were feasibly applied in physics learning based on physics learning characteristics. Bloomian HOTS is better applied based on compliance with national curriculum demands, practicality, and efficiency.
\end{abstract}

Keywords-assessment, Bloomian HOTS, Marzanoian HOTS, physics learning

\section{INTRODUCTION}

Assessment is a very important process in physics learning. A study by [1] stated that assessment informs the student's expectation in a lesson. Assessment can be interpreted as the result of interpreting data of a measurement based on criteria, standards, or certain rules [2]. Assessment is also a major factor to improve the ability of students. Kusairi [3] mentioned the importance of assessment conducted by teachers in the learning process. Assessment activities can help teachers to understand the strengths and weaknesses experienced by students in learning. The more qualified the instructional learning activities, the better the teacher's understanding of the weaknesses and strengths of students in learning a particular subject material. As there are still limited studies concerning the assessment by teachers to measure student's high-order thinking skills (HOTS), there is a need to produce a test instrument at such level. This case is observed from the portraits of education quality in various countries, which is still not satisfying, especially in developing countries, such as Indonesia. The evaluation results of Trends in Student Achievement in Mathematics and Science [4] for science grade VIII presented that Indonesia occupies the fifth position from below (with Macedonia, Lebanon, Morocco, and Ghana). Indonesia is in 39th place from 42 countries with a score of 406 below Palestine, Malaysia, and Thailand [4]. To improve the education quality in Indonesia, it is important to assess the higher cognitive domain.

Assessment categories used in the cognitive domain according to the revised Bloom's Taxonomy are divided into lower order thinking skills (LOTS) and higher order thinking skills (HOTS). The commonly used instruments are assessment instruments with LOTS, including test assessments that are mostly only in the knowledge levels of C1 (remember), C2 (understand), and C3 (apply). Students are not accustomed to answer questions in the levels of $\mathrm{C} 4$ (analyze), C5 (evaluate), and C6 (create) [5]. Moreover, test assessments are still rarely found at the levels of $\mathrm{C} 4, \mathrm{C} 5$, and C6. HOTS which includes the ability to analyze, evaluate, and create is called Bloomian-HOTS. Thus, it is necessary to develop assessments in the form of Bloomian-HOTS test.

Physics is one of the most challenging subjects. Hence, it is considered as an important topic for teachers to be able to make the learning process to run efficiently. Therefore, one of the most important ideas in physics is finding suitable ways to maximize the learning productivity and learning outcomes. One of the most important factors affecting physics learning and teaching is the organization of physics knowledge and the ability to organize and represent the correct concepts. The factors supporting the success of physics learning begins with the correct understanding of the concept to students. Teachers must consider different levels of student's thinking ability, both for high and low level 
capabilities. The end result of the development of teaching and learning process is the assessment. Physics learning in high school demands high-level reasoning skills to understand and analyze the concepts, laws, theories of natural phenomena. The nature of physics learning is physics as a science that becomes a foundation in the development of different types of technology. Hence, physics needs to be learned as a theory that guides students and therefore must be HOTS oriented.

HOTS or so-called higher order thinking basically means higher levels of thinking, based on a hierarchy of cognitive processing abilities. Ramos, et al [6] stated that the most widely accepted hierarchical structure of students thinking level in education is Bloom's taxonomy. Bloom's taxonomy has so far been revised. Bloom's old taxonomy was revised by [5] which is known as revised Bloom's taxonomy (Bloomian). HOTS tests can be designed by displaying concepts, visualizations, analogies, schemes, and conclusions. Marzano's new taxonomy consists of cognitive ability of the knowledge recall, comprehension, analysis, and knowledge utilization. Hence, higher-level thinking by both HOTS theories may be used to measure higher order thinking ability via HOTS instruments. It is expected that the application of HOTS may produce effective learning lessons. Based on the description above, it is essential to implement Bloomian and Marzanoian HOTS tests in physics learning assessment.

The Bloomian-HOTS refers to the revised Bloom taxonomy. The cognitive domain in the popular revised Bloom's taxonomy is the higher order thinking ability of students that includes the ability to analyze, evaluate, and create following the $\mathrm{C} 4, \mathrm{C} 5$, and C6 levels, respectively, of the revised Bloom taxonomy [5]. According to [5], the original taxonomy consists of six categories as shown in Fig. 1. Each aspect has sub-aspects.

The taxonomy scheme is organized within the framework of cumulative hierarchy where achievement of skills or abilities is more complex than ever. The goal of taxonomy is to emphasize the learning assessment with many sample test items for each category. Fig. 1. shows the revised Bloom's taxonomy where the higher levels include analyzing, evaluating, and creating each of which is divided into several aspects such as presented in Table 1. HOTS which include analyzing, evaluating, and creating are a complex concept and thinking with various solutions [7].

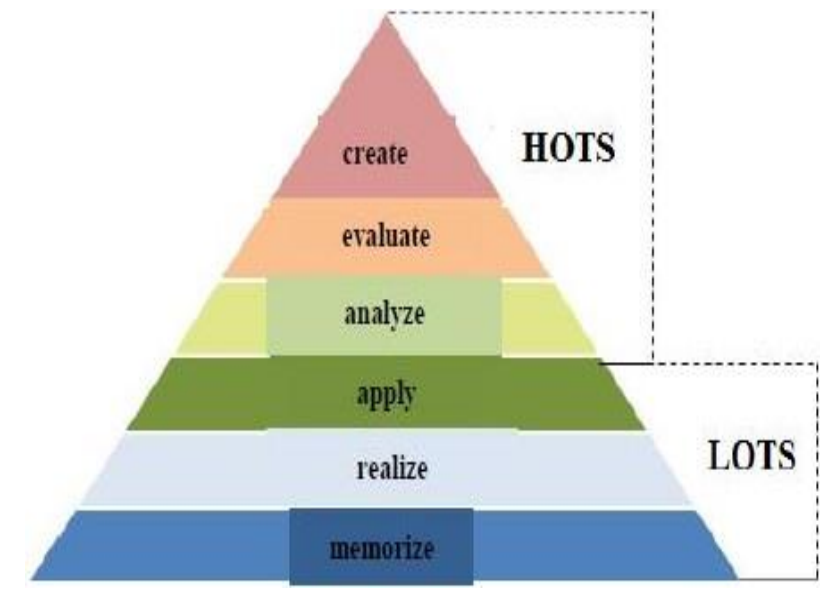

Fig. 1. The Revised Bloom's Taxonomy Pyramid

TABLE I. COGNITIVE DIMENSIONS OF HOTS ACCORDING TO THE REVISED BLOOM'S TAXONOMY

\begin{tabular}{|l|l|}
\hline $\begin{array}{l}\text { Cognitive aspect } \\
\text { and sub-aspect }\end{array}$ & \multicolumn{1}{c|}{ Operational Definition } \\
\hline \multicolumn{1}{|c|}{ Analyzing } \\
\hline Differentiating & $\begin{array}{l}\text { Distinguishing relevant sections of a subject material } \\
\text { from the irrelevant ones, distinguishing important } \\
\text { parts of the subject matter from the non-essential } \\
\text { ones. }\end{array}$ \\
\hline Organizing & $\begin{array}{l}\text { Determining how elements work or function in a } \\
\text { structure or sequence. }\end{array}$ \\
\hline Attributing & $\begin{array}{l}\text { Determining the point of view, bias, value, or } \\
\text { purpose behind the subject matter. }\end{array}$ \\
\hline \multicolumn{1}{|c|}{ Evaluate } \\
\hline Checking & $\begin{array}{l}\text { Determining inconsistencies or errors in a process or } \\
\text { product, finding the effectiveness of a procedure } \\
\text { being practiced }\end{array}$ \\
\hline Critiquing & $\begin{array}{l}\text { Finding inconsistencies between a product and an } \\
\text { external criterion: determining whether a product has } \\
\text { an external consistency; determining the accuracy of } \\
\text { a procedure to resolve the problem. }\end{array}$ \\
\hline \multicolumn{1}{|c|}{ Create } \\
\hline $\begin{array}{l}\text { Generating } \\
\text { Planning }\end{array}$ & \begin{tabular}{l} 
Making hypotheses based on criteria \\
Planning procedures for completing a task \\
\cline { 2 - 4 }
\end{tabular} \\
\hline
\end{tabular}

Marzanoian refers to HOTS according to Marzano. Marzano divides the cognitive system into four components, i.e.: knowledge recall, understanding, analysis, and knowledge use [8]. Each process is formed from all previous processes. Understanding, for example, requires the withdrawal of knowledge; analysis requires understanding, and so on. The knowledge recall is similar to the knowledge component of Bloom's taxonomy. Knowledge recall involves recalling information from a fixed memory. At this level of understanding, students recall more facts, sequences, or processes just as they exist. Understanding is a higher level. Understanding demands the identification of what is important to remember and puts information into appropriate categories [9]. Therefore, the early skills of understanding and synthesis require the identification of the most important components of a concept and the omission of all insignificant ones. Analysis is more complex than simple understanding. The five cognitive processes in analysis are adjustment, classification, error analysis, and specification. 
By engaging in these processes, students can use what they learn to generate new insights and discover ways to use what they have learned in new situations. The use of end-level knowledge of cognitive processes addresses the use of knowledge [10]. Marzano calls these processes a use of knowledge or knowledge use. The process of using knowledge is a critical component of thinking for projectbased learning since it incorporates various processes used by many people when they want to accomplish a specific task.

Improving high-level thinking skills has become one of the priorities in physics learning. To achieve this objective in detail it is necessary to practice HOTS. A valid, reliable, objective, and practical high-level thinking assessment instrument is required to measure the high-level thinking ability of students. The poor ability of teachers in measuring the high-level thinking ability of students is a definite reason to develop a test to measure HOTS.

This statement is supported by the results of [1] suggesting that many teachers fail to provide questions of the knowledge content of student's thinking skills. Teachers can only ask questions on the aspect of student's memories that are the part of lower order thinking skills (LOTS). Hence, it is necessary to construct questions which really measure high-level thinking skills. Madhuri, et al [11] addressed that active learning that promotes high-level thinking skills plays an important role in the education system.

The purpose of introducing HOTS is to improve the assessment system in the 21 st century in many developed countries. In fact, the use of HOTS for assessment began to be applied in the education system by the government. HOTS help students to move from one phase to another. Hence, it is very important for students to be accustomed to work on problems with HOTS. The emphasis on HOTS begins with teachers. Educators should design learning and assessing using HOTS, so as to gain a better understanding and adapt to HOTS.

TABLE II. COGNITIVE DIMENSIONS OF HOTS ACCORDING TO MARZANOIAN

\begin{tabular}{|c|c|c|}
\hline No & Cognitive Aspect & Operational Definitions \\
\hline \multirow[t]{2}{*}{1} & \multirow[t]{2}{*}{ Knowledge Recall } & Emphasizing on the underlying theme \\
\hline & & $\begin{array}{l}\text { Using criteria to choose (from a variety of } \\
\text { choices) }\end{array}$ \\
\hline \multirow[t]{2}{*}{2} & \multirow[t]{2}{*}{ Analysis } & $\begin{array}{l}\text { Formulating the principles from the } \\
\text { available evidence }\end{array}$ \\
\hline & & Applying the principles to draw conclusion \\
\hline \multirow[t]{5}{*}{3} & \multirow{5}{*}{ Comprehension } & Emphasizing on similarity and difference \\
\hline & & Classifying objects into categories \\
\hline & & Criticizing thinking (way of thinking) \\
\hline & & Supporting a statement \\
\hline & & $\begin{array}{l}\text { Emphasizing on personal views concerning } \\
\text { an issue }\end{array}$ \\
\hline \multirow[t]{4}{*}{4} & \multirow{4}{*}{$\begin{array}{l}\text { Knowledge } \\
\text { Utilization }\end{array}$} & Calling for information \\
\hline & & Overcoming problems \\
\hline & & Trying to find an explanation \\
\hline & & Obtaining the best method \\
\hline
\end{tabular}

From the results of literature studies and from interviews with high school physics teachers in Yogyakarta Special Region, only a few teachers conduct HOTS assessment in physics learners. This phenomenon is due to, among other things, limited availability of HOTS physics assessment instruments. Rarely do assessments are developed to measure high-level thinking skills of students. The type of tests in the semester or national exams is in the form of multiple choices [12]. To measure the high-level thinking skills of students the tests should be in the form of reasoning multiple-choices tests as a development of the usual multiple-choice tests [13]. Based on the above description, it is necessary to examine the construction and characteristic of Bloomian and Marzanoian HOTS assessment instrument parameters and also the feasibility of implementing of HOTS in high school physics learning assessment.

\section{METHOD}

The development model used in this study was a modification of the Wilson and Oriondo-Antonio models. The stages of the development are given as follows: 1) design of test, 2) trial test, and 3) assembling test. After the instrument drafted the content, the validity test was conducted by experts and practitioners. Based on the inputs and feedbacks from the validators, a revision was made on the items of the instrument. After the revision had been completed, the items were then assembled into a test instrument set.

The respondents used for instrument of trial test in Yogyakarta Special Region were 737 senior high school students of grade $\mathrm{X}$ divided into two groups. The first group of 437 students was tested using Bloomian HOTS. The second group consisting of 300 students was tested using the Marzanoian HOTS test instrument. The subject matter tested was the physics materials in class $\mathrm{X}$ of senior high school which were Elasticity and Hooke's law, Temperature and Heat, Static Fluids, and Optical Instruments. The developed tests consisted of two sets of multiple-choices questions with reasoning that included both Bloomian and Marzonian HOTS aspects.

The data collection techniques included test and non-test techniques. The test technique was used to measure student's high-level thinking skills, while the non-test technique utilized questionnaire to measure the effectiveness of its application with the respondents of senior high school physics teachers. The stages of the model development are stated in Fig. 2.

\section{RESULTS AND DISCUSSION}

The tests which were conducted in this study resulted in two parts namely Bloomian and Marizonian HOTS. Comparison was conducted upon HOTS tests according to Bloom and Marzano in terms of cognitive aspects. The cognitive aspects which was analyzed used literature study and reinforced by some study results. The analysis between Bloomian and Marizonian HOTS was divided into two parts. 


\section{A. Construction and Characteristics of Bloomian and} Marzonian HOTS

\section{1) Aspect and Sub-Aspect}

According to Table 3, the same aspect of Bloomian and Marzanoian HOTS is found in the analysis aspect. The analysis aspect of Bloomian HOTS emphasized on breaking down the material into its constituent parts, determining the relationships between the parts and also the overall structure or objective. On the other hand, the analysis aspect of Marzanoian HOTS Marzonian emphasized on similarities and differences, grouping things into categories, criticizing thoughts (thinking), supporting statements, and emphasizing personal views on an issue. Thus, the analysis aspect of both HOTS is a high-level cognitive Skills of category C4 according to Bloom taxonomy.

The examples of test items with the same analysis aspect elaborated according to each HOT are given as follows. The differences presented in the test items in Table 4 can be observed from the predetermined indicator. Information obtained from Bloomian HOTS test was more towards multirepresentation ability of students. In solving the test items, the students were required to more accurately determine the information contained in the picture and present it in the form of mathematical and verbal solutions. On the other hand, the HOTS test according to Marzanoian is more towards the solution that requires students with their basic skills of knowledge and to connect the concept of causality based on experience.

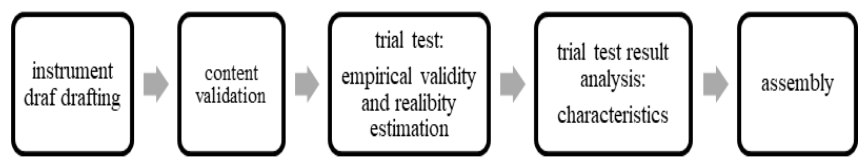

Fig. 2. Instrument Development Stages

TABLE III. ASPECT AND SUB-ASPECT DIFFERENCES BETWEEN BLOOMIAN AND MARZANOIAN HOTS

\begin{tabular}{|c|c|c|c|}
\hline \multicolumn{2}{|c|}{ Bloomian HOTS } & \multicolumn{2}{|c|}{ Marzanoian HOTS } \\
\hline $\begin{array}{c}\text { Bloomian } \\
\text { Aspect }\end{array}$ & $\begin{array}{c}\text { Bloomian Sub- } \\
\text { aspect }\end{array}$ & $\begin{array}{c}\text { Marzonian } \\
\text { Aspect }\end{array}$ & $\begin{array}{c}\text { Marzonian Sub- } \\
\text { aspect }\end{array}$ \\
\hline \multirow{6}{*}{$\begin{array}{l}\text { Analyzing } \\
\text { (C4) }\end{array}$} & \multirow{2}{*}{$\begin{array}{l}\text { Differentiating } \\
\text { Organizing }\end{array}$} & \multirow{2}{*}{$\begin{array}{l}\text { Retrieval } \\
\text { Knowledge }\end{array}$} & Abstracting \\
\hline & & & Decision making \\
\hline & \multirow[t]{4}{*}{ Attributing } & \multirow[t]{4}{*}{ Analysis } & Comparing \\
\hline & & & Error analysis \\
\hline & & & $\begin{array}{l}\text { Support } \\
\text { constructing }\end{array}$ \\
\hline & & & $\begin{array}{l}\text { Perspective } \\
\text { analysis }\end{array}$ \\
\hline \multirow[t]{2}{*}{$\begin{array}{l}\text { Evaluating } \\
\text { (C5) }\end{array}$} & Checking & \multirow[t]{2}{*}{ Comprehension } & $\begin{array}{l}\text { Inductive } \\
\text { reasoning }\end{array}$ \\
\hline & Critiquing & & $\begin{array}{l}\text { Deductive } \\
\text { reasoning }\end{array}$ \\
\hline \multirow{4}{*}{$\begin{array}{l}\text { Creating } \\
\text { (C6) }\end{array}$} & Generating & \multirow{4}{*}{$\begin{array}{l}\text { Knowledge } \\
\text { Utilization }\end{array}$} & Investigating \\
\hline & Planning & & Problem-solving \\
\hline & \multirow[t]{2}{*}{ Producing } & & Experiencing \\
\hline & & & Discovering \\
\hline
\end{tabular}

TABLE IV. EXAMPLE OF HOTS TEST ITEM

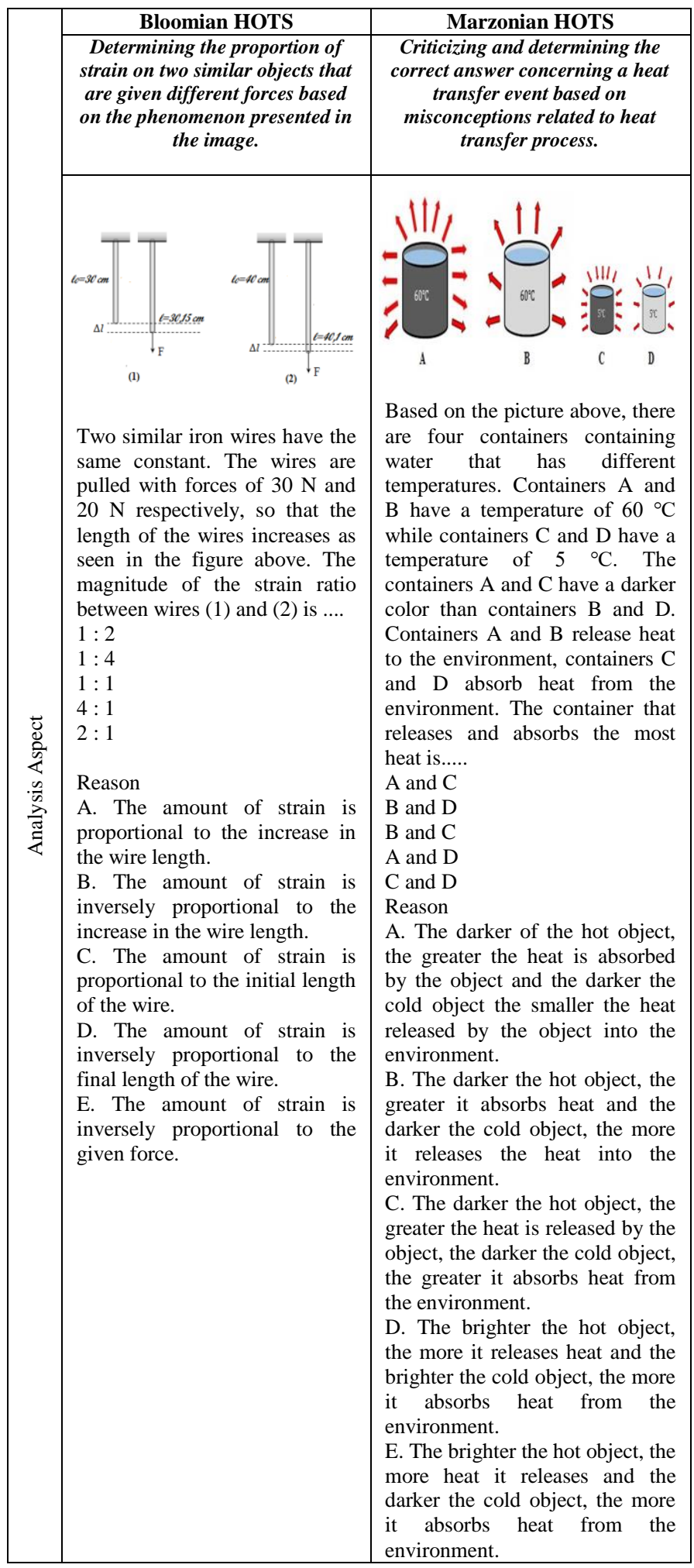

1) Aspects of Test and Item Parameter Characteristics

The characteristics of test item parameters are viewed from validation, reliability, and difficulty index. Based on the responses and assessments of four assessment experts from physics education and two physicists, the value of $\mathrm{V}$ 
Aiken index was 0.73 for Bloomian HOTS and 0.89 for Marzanoian HOTS so that the overall items that had been developed were valid according to experts judgment and could be used in the next phase trial test, i.e.: empirical trial test. This case is in accordance with the stage of interpretation conducted by [14] where the overall items were valid if they were between the range of $0.67-1.00$.

After going through the expert validation, the HOTS test instrument was assembled into two packages of tests, namely packet $\mathrm{A}$ and packet $\mathrm{B}$ used in the empirical trial test phase. The results of the empirical tests, and the results of item and test estimations are shown in Table 5.

Goodness of fit for Bloomian and Marzanoian HOTS were tested with an item acceptance limit using infit MNSQ between values 0.77 to 1.30 . Based on the analysis of infit, MNSQ Bloomian and Marzanoian HOTS were in the ranges of 0.88 to 1.13 and 0.77 to 1.11 , respectively, so that the whole Bloomian and Marzanoian HOTS instrument items were fit with the PCM model.

The difficulty index analysis of 125 HOTS test items is between -1.74 to 1.14 . This is in accordance with the theory by [15] stating that a good degree of difficulty is obtained if the value of the items difficulty index is between -2 and +2 . The highest difficulty indexes for Bloomian and Marzanoian HOT, the tests are found for the aspects of creation and knowledge utilization with values of 0.41 and 0.5 , respectively. A more detailed comparison is shown in Fig. 3.

TABLE V. ESTIMATION RESULTS

\begin{tabular}{|c|c|c|c|c|c|}
\hline \multirow{3}{*}{$\begin{array}{l}\text { No } \\
1\end{array}$} & \multirow{3}{*}{$\begin{array}{l}\text { Descriptions } \\
\text { average and } \\
\text { standard } \\
\text { deviation } \\
\end{array}$} & \multicolumn{2}{|c|}{ Bloomian-HOTS } & \multicolumn{2}{|c|}{ HOTS- Marzanoian } \\
\hline & & $\begin{array}{c}\text { Item } \\
\text { Estimation } \\
\end{array}$ & $\begin{array}{c}\text { Test } \\
\text { Estimation } \\
\end{array}$ & $\begin{array}{c}\text { Item } \\
\text { Estimation }\end{array}$ & $\begin{array}{c}\text { Test } \\
\text { Estimation }\end{array}$ \\
\hline & & $\begin{array}{l}-0,01 \quad \pm \\
0,61\end{array}$ & $\begin{array}{l}-0,49 \\
\pm 0,36\end{array}$ & $\begin{array}{ll}-0,02 & \pm \\
0,28 & \end{array}$ & $\begin{array}{ll}-0,29 & \pm \\
0,18 & \end{array}$ \\
\hline 2 & Reliability & 0,71 & 0,73 & 0,83 & 0,87 \\
\hline 3 & $\begin{array}{l}\text { INFIT } \\
M N S Q \\
\text { average and } \\
\text { standard } \\
\text { deviation } \\
\text { values } \\
\end{array}$ & $\begin{array}{l}1,00 \quad \pm \\
0,05\end{array}$ & $\begin{array}{l}1,01 \\
0,25\end{array}$ & $\begin{array}{ll}1,00 & \pm \\
0,08 & \end{array}$ & $\begin{array}{ll}0,99 & \pm \\
0,17 & \end{array}$ \\
\hline 4 & $\begin{array}{l}\text { OUTFIT } \\
M N S Q \\
\text { average and } \\
\text { standard } \\
\text { deviation } \\
\text { values } \\
\end{array}$ & $\begin{array}{l}1,04 \quad \pm \\
0,26\end{array}$ & $\begin{array}{ll}1,06 & \pm \\
0,66 & \end{array}$ & $\begin{array}{ll}0,96 & \pm \\
0,10 & \end{array}$ & $\begin{array}{l}0,96 \quad \pm \\
0,12\end{array}$ \\
\hline 5 & $\begin{array}{lr}\text { INFIT } t \\
\text { average and } \\
\text { standard } \\
\text { deviation } \\
\text { values } \\
\end{array}$ & $0,00 \pm 0,57$ & $\begin{array}{l}-0,10 \\
\pm 1,11\end{array}$ & $\begin{array}{ll}0,21 & \pm \\
1,68 & \end{array}$ & $\begin{array}{ll}0,29 & \pm \\
1,31 & \end{array}$ \\
\hline 6 & $\begin{array}{lr}\text { OUTFIT } t \\
\text { average and } \\
\text { standard } \\
\text { deviation } \\
\text { values }\end{array}$ & $0,14 \pm 1,10$ & $\begin{array}{l}0,06 \\
0,66\end{array}$ & $\begin{array}{ll}-0,51 \quad \pm \\
1,28\end{array}$ & $\begin{array}{ll}-0,18 \quad \pm \\
0,43\end{array}$ \\
\hline
\end{tabular}

Based on the data analysis, the reliability values obtained were 0.71 and 0.83 for Bloomian and Marzanoian HOTS, respectively. The figure shows the reliability values in the range 0.67 to 0.80 , with the interpretation of the test reliability which was categorized as sufficient.

2) The Implementation Feasibility of Bloomian and Marzanoian HOTS in Physics Learning Assessment

Improving HOTS has become one of the priorities in physics learning. As expected in one of the 2013 curriculum knowledge Core Competencies explaining that students are expected to be able to understand, apply, and analyze factual knowledge, conceptual, procedural, and meta-cognitive knowledge based on their curiosity about science through an assessment. This case is in accordance with the capabilities demanded in the 21st century. The implementation feasibility of HOTS can be explained below. Based on the aspects and sub-aspects stated in Table 4, Bloomian and Marzanoian HOTS are feasible to be applied in physics learning. Based on the information function and SEM as observed in Fig. 4. Bloomian and Marzanoian HOTS are feasible to be applied in physics learning.

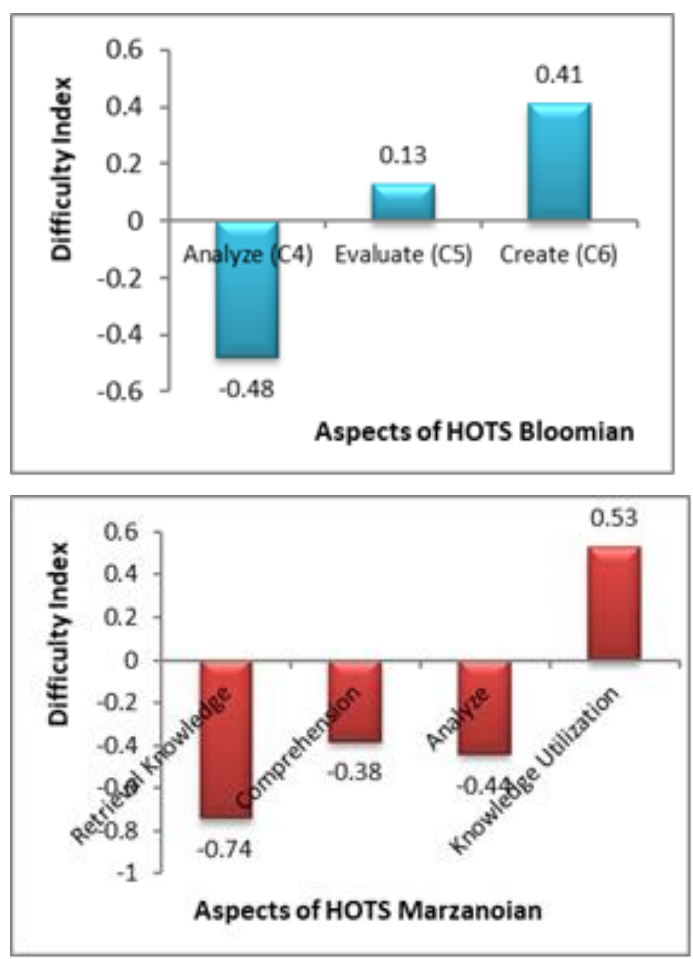

Fig. 3. Item Difficulty Index on the Aspect of (a) Blooomian and (b) Marzanoian HOTS 

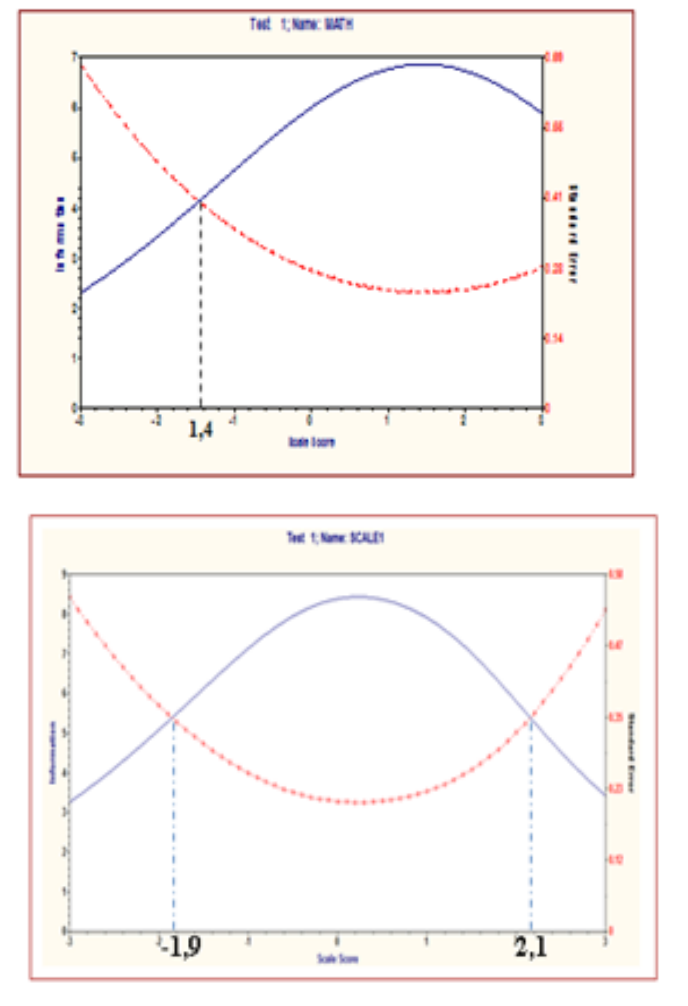

Fig. 4. Relationship of Information Functions and SEM (a) Bloomian and (b) Marzanoian HOTS

According to Fig. 4. and in accordance with the theory by [15]which states that if the relationship between the SEM and information function is inversely proportional, the higher the SEM the lower the information function is obtained, and vice versa. Based on Fig. 4. The Bloomian and Marzanoian HOTS test instruments are suitable for students with abilities of $(\theta \geq-1.4)$ and $(-1.9 \leq \theta \leq 2.1)$, respectively.

The responses of senior high school physics teachers in Yogyakarta Special Region towards the application of Bloomian and Marzanoian HOTS are stated in Table 6. Based on the responses of senior high school physics teachers, Bloomian and Marzanoian HOTS are feasible to be applied in physics learning. However, the Bloomian HOTS is better applied in measuring the student's HOTS in accordance with national curriculum demands. Moreover, Marzanoian HOTS remains applicable in the physics learning assessment.
TABLE VI. RESPONSES OF PHYSICS TEACHERS TOWARD BLOOMIAN AND MARZANOIAN HOTS.

\begin{tabular}{|c|c|c|}
\hline Aspect & Statements & $\begin{array}{c}\text { Teacher } \\
\text { Response } \\
\text { Percentage } \\
\text { of 'Yes' } \\
\text { Answer }\end{array}$ \\
\hline \multirow{6}{*}{$\begin{array}{l}\text { Compatibility } \\
\text { with Physics } \\
\text { and } \\
\text { curriculum } \\
\text { Learning } \\
\text { characters }\end{array}$} & $\begin{array}{l}\text { 1. Bloomian HOT is in accordance with } \\
\text { the character of physics learning in high } \\
\text { school. }\end{array}$ & 85 \\
\hline & $\begin{array}{l}\text { 2. Marzanoian HOT is in accordance with } \\
\text { the character of physics learning in high } \\
\text { school. }\end{array}$ & 80 \\
\hline & $\begin{array}{l}\text { Bloomian HOTS is in accordance with the } \\
\text { mandate of the national curriculum in } \\
\text { senior high school physics learning } \\
\text { assessment. }\end{array}$ & 100 \\
\hline & $\begin{array}{l}\text { Marzanoian HOTS is in accordance with } \\
\text { the mandate of the national curriculum in } \\
\text { senior high school physics learning } \\
\text { assessment. }\end{array}$ & 60 \\
\hline & $\begin{array}{l}\text { Bloomian HOTS is more in line with the } \\
\text { mandate of the national curriculum than } \\
\text { Marzanoian HOTS in senior high school } \\
\text { physics learning assessment. }\end{array}$ & 100 \\
\hline & $\begin{array}{l}\text { 6. Bloomian and Marzanoian HOTS have } \\
\text { the same suitability with the national } \\
\text { curriculum in senior high school physics } \\
\text { learning assessment. }\end{array}$ & 70 \\
\hline \multirow[t]{4}{*}{ Practical } & $\begin{array}{l}\text { 7. Bloomian HOTS is better known than } \\
\text { Marzanoian HOTS in the learning physics } \\
\text { assessment by teachers in senior high } \\
\text { school. }\end{array}$ & 85 \\
\hline & $\begin{array}{l}\text { 8. Bloomian HOTS is easy to apply in the } \\
\text { assessment of learning physics in senior } \\
\text { high school. }\end{array}$ & 80 \\
\hline & $\begin{array}{l}\text { 9. Marzanoian HOTS is easy to apply in } \\
\text { the assessment of learning physics in } \\
\text { senior high school. }\end{array}$ & 70 \\
\hline & $\begin{array}{l}\text { 10. Bloomian HOTS is easier to apply than } \\
\text { Marzanoian HOTS in the physics learning } \\
\text { assessment in senior high school. }\end{array}$ & 85 \\
\hline \multirow[t]{2}{*}{ Effective } & $\begin{array}{l}\text { 11. Bloomian HOTS items are compiled } \\
\text { faster than Marzanoian HOTS by physics } \\
\text { teachers in senior high school. }\end{array}$ & 95 \\
\hline & $\begin{array}{l}\text { 12. Blooomian HOTS items have more } \\
\text { variation in each indicator than } \\
\text { Marzanoian HOTS. }\end{array}$ & 90 \\
\hline
\end{tabular}

\section{CONCLUSION}

Based on the data analysis in the above results and discussion, it can be concluded that Bloomian HOTS consists of three aspects which are divided into eight subaspects with 65 items, while HOTS Marzanoian consists of five aspects divided into 13 sub-aspects with 65 items. All items with subject materials of Hooke's Law, Static Fluids, Temperature and Heat, and Optical Devices were all valid, fit with PCM, and reliable.

Bloomian and Marzanoian HOTS are feasible applied in physics learning based on physics learning characteristics. HOTS Bloomian is better than Marzanoian HOTS based on compliance with national curriculum demands, practicality, and efficiency. 


\section{REFERENCES}

[1] J. L. Jensen, M. A. McDaniel, S. M. Woodard, and T. A. Kummer, "Teaching to the test... or testing to teach: Exams requiring higher order thinking skills encourage greater conceptual understanding," Educ. Psychol. Rev., vol. 26, no. 2, pp. 307-329, 2014.

[2] S. Widoyoko and P. Eko, Assessment of learning outcomes in school. Yogyakarta: Pustaka Pelajar, 2014.

[3] S. Kusairi, "Physics Formative Assessment Analysis in Senior High School Assisted by Computer," J. Penelit. dan Eval. Pendidik., 2012.

[4] M. O. Martin, I. V. Mullis, and A. M. Kennedy, Progress in International Reading Literacy Study (PIRLS): PIRLS 2006 Technical Report. Boston: TIMSS \& PIRLS International Study Center, 2007.

[5] A. Anderson and K. Krathwohl, Basic framework for learning, teaching and assessment. Yogyakarta: Pustaka Belajar, 2001.

[6] J. L. S. Ramos, B. B. Dolipas, and B. B. Villamor, "Higher order thinking skills and academic performance in physics of college students: A regression analysis," Int. J. Innov. Interdiscip. Res., vol. 1, no. 4, pp. 48-60, 2013.

[7] B. Miri, B. C. David, and Z. Uri, "Purposely teaching for the promotion of higher-order thinking skills: A case of critical thinking," Res. Sci. Educ., vol. 37, no. 4, pp. 353-369, 2007.

[8] R. J. Marzano, B. B. Gaddy, and C. Dean, "What Works In Classroom Instruction," 2000.

[9] R. J. Marzano, "A Theory-Based Meta-Analysis of Research on Instruction By," 1998.

[10] Y. M. Heong, W. B. O, J. B. M. Y, T. T.K, R. B., and M. M.B.M., "The Level of Marzano Higher Order Thinking Skills among Technical Education Students," Int. J. Soc. Sci. Humanit., vol. 1, no. 2, 2011.

[11] G. V. Madhuri, A, V. S. S. N. Kantamreddi, A, and L. N. S. Prakash, Goteti., "Promoting higher order thinking skills using inquiry-based learning," Eur. J. Eng. Educ., vol. 37, no. 2, pp. 117-123, 2013.

[12] E. Istiyono, "Measurement of Higher-Order Thinking Skills in Physics for High School Students in Yogyakarta Special Regioin," State University Yogyakarta, 2013.

[13] E. Istiyono, D. Margapi, and S. Suparno, "Effectiveness of MultipleChoice Test with Reasoning to Measure Higher-Order Thinking Skills in Physics an Implementation of 2013 Curriculum," in Proceeding of International Conference on Educational Research and Evaluation (ICERE), 2014.

[14] D. N. Kowsalya, H. Venkat Lakshmi, and K. P. Suresh, "Development and Validation of a Scale to assess Self-Concept in Mild Intellectually Disabled Children," Int. J. Soc. Sci. Educ., vol. 2, no. 4, 2012.

[15] H. Hambleton and S. Swaminathan, Fundamentals of Item Response Theory. California: SAGE Publications, Inc, 1991. 